\title{
Semiotic of Symbolic Mode in Interpreting Mythology in English Poetry
}

\author{
Mulyoso \\ Graduate Student of Universitas Negeri Malang
}

\begin{abstract}
This paper is primarily based on the assumption that we need theories of literature in order to interpret the literary texts and explain literature as a unique form of communication. The so - far traditional efforts of treating literary study as an intuitive analysis has contributed to the harsh criticism on the study of literature as merely "the reading and understanding of literature'. Literature teaching has given too much emphasis on the enjoying and understanding of a literary piece, that is to say that merely by understanding the meaning of the language of a text, its cultural references, one is said to be in a position to respond critically to that text-thus there is no need for interpretation beyond that. Therefore, this paper is an attempt to interpret a literary text (mythology in English poetry) beyond its literal level by the use of semiotics of symbolic mode approach which allows the intertextual and intratextual analysis.
\end{abstract}

Keywords: semiotics, symbolic mode, interpretation, myth

A striking feature of the teaching of English literature, be it in English speaking countries or non-speaking ones, has been the emphasis on the effort of finding the usefulness of literature. Charlotte S. Huck, the writer of Children's Literature in the Elementary School (1976), for instance, wrote the usefulness of literature for children as follows: to provide enjoyment, to develop imagination, to give vicarious experience, to develop insight into human behavior, to present universality of human experience. It is also not uncommon to find teachers in both an English- speaking and non English-speaking context attempting to achieve the aim of using literature as the medium of learning language in use. There is a tendency to see literature as just another use of language and literature study as just another 
subject on curriculum, which has led to the neglect of features which mark literature as a discourse and an area of study demanding different techniques of description and different pedagogical approaches.

There might be nothing wrong with such an effort except for some particular reasons. First, teachers in English speaking context may still endeavor to hold the usefulness principle as far as the literature program is designed carefully for children based on their needs, interests, and cognitive development. But we cannot expect too much that some literary works may still be attractive to children today who have enjoyed more "fascinating " presentation of experience via television or movie. Besides, we must be aware that we do not expect to treat literature in this way when we are facing the adult students such as the university students. It would be silly to think that university students even in non English - context can learn something from Dickens' Great Expectations or Sheridan's School for Scandal. Second, as Lotman (1970) pointed out that literature is a product of minimally two overlapping systems; linguistics and literature so that it can be considered as a 'secondary modeling system'. Hence the system of literature is supralingual wherein the recipient of the linguistic message must firstly know the linguistic code in order to interpret a text. That is to say that a literary reader must have the knowledge of literary code besides the linguistic code used to convey the message in the text. At this point, it becomes obvious that literature cannot be used as a language communication model for language students without causing some disorders. We cannot surely use the following Shakespeare's word class conversion of the noun 'boy' to a verb as cited by Widdowson (1975): "And I shall see some squeaking Cleopatra boy my greatness". Jacobson (1960) states the difference between the literary or poetic and the daily language as follows: "the poetic function projects the principle of equivalence from the axis of selection into the axis of combination". The consequence is clear-cut, expression such as alive he drive can be accepted in literary language but not in daily one. Third, althou gh it is true that the majority of modern critics make a distinction between the enjoyment of literature reading and interpretation (see Newton, 1990), at the university level we must carefully separate the two and put more emphasis on the interpretation. Literature teaching should provide students with the ability of recognizing the quality of literary works (literariness) and try to analyze the patterns or the universal concepts of literature.

The literature study in the twentieth century has undergone a series of devel- opments focusing on at least three aspects (a) autonomy of the text such as held by Formalism and Structuralism (b) the mimeticism of the text such as held by Marxism (3) the reader's role held by the so-called receptional aesthetics. Those theories have lately developed into some versions such as the schema theory (Cook, 1994) that focuses on the three schemata of the readers; the text schemata, the world schemata, and the language schemata. Each of the theories has certainly some weaknesses and quite possibly that each one serves as a complementary to the others. This article is designed to use the Semiotic approach of symbolic mode in which a text is not merely interpreted on the basis of its literal meaning but its symbolical aspect (the message). Semiotics is chosen here for two reasons. First, ever since the publication of Eco's Theory of Semiotics (1976), the question of the truth has been neglected. Literature is obviously characterized by what Spet (in Fokkema and Kunne Ibsch, 1994) called "the third type of truth" since, as a matter of fact, literature very frequently informs us many "fantastic things" which reference cannot be approached by logics such as ' a speaking horse in Tolstoy's Kholstomer', By rejecting the concept of 'referential fallacy', Eco (1976: 58-59) decides to include literature into one of the objects studied in Semiotics. Second, Semiotics opens the possibility of interpreting a text on the basis of intertextuality as well as intratextuality since it covers a wide range of disciplines.

\section{THE SYMBOLIC MODE OF MYTH IN ENGLISH POETRY}

Morris wrote in his Foundations of the Theory of Sign (1938: 1) that "human civilization is dependent upon signs and system of signs, and the human mind is inseparable from the functioning of signs - if indeed mentality is not to be identified with such functioning". This leads him as to believe that the concept of sign may prove as fundamental to the sciences of man as the concept of atom has been for the physical sciences or the concept of cell for the biological sciences (1938: 42). This belief seems not to be too exaggerated if we notice what appears to be an agreement among the semioticians, defined more as those who label their works as semiotic such as Eco, Sebeok, etc. rather than those who in fact practice semiotic studies but do not label them so, that the subject matter of semiotics covers the whole range of cultural phenomena including the phenomena produced by animals (zoosemiotics) and flora (phytosemiotics). We can easily notice in many 
walks of our daily life, be they political, economical, or social-cultural, men still employ largely what in general we call 'sign'. The politicians speak of their programs and messages via signs hence there we meet the emblems, coat of arms, flags as the signs related to a political party and ideology. It may be curious enough that in the same time we can recognize easily that some of the 'signs' used by modern people are existentially the same with those used in the long past. Myth, for instance, has been used by modern people surprisingly as "communicating signs" as the ancient people did. The difference only lies on the content but the substance remains the same. Sorel in the Reflexions on Violence (1914) considers that the world labour strike is a myth for it represents the motivation and supports for the labours.

Despite the well-known acceptance on the standard definition of semiotics as the 'general theory of sign' (see Sebeok, 1986; Deely, 1982), the meaning of sign itself indicates the problems commonly faced by the semioticians. Peirce (1985) divides sign into three kinds (a) icon : a sign that refers to the object that it denotes by virtue of characters of its own (b) index : a sign which refers to the object that it denotes by virtue of being really affected by that object (c) symbol : a sign which refers to its object that it denotes by virtue of a law, usually an association of general ideas. Here it is obvious that Peirce has used the term 'sign' as the genus generallisimum of semiotics, symbol is said to be the subclass of sign. Whereas in fact, many people call symbols what others call signs, but fewer people who call signs what others call symbols(see Eco, 1986). In other words, concerning the couple symbol/sign, the first term is the marked one. This explains a lot of things. First, in the Peircean sense, symbols are expressions that mean directly and univocally what they are designed to mean such as the scientific symbols in chemistry, mathematics or physics. 'Symbols', in Peircean sense, are then those conventional 'signs' whose meanings are not vague and pre-established. Second, Symbols are often associated with the indirect meaning or an additional intended meaning that sentences may have (Grice, 1957). The sentence "I saw your wife in a hotel with a young man" cannot be interpreted literally, but must go beyond the prima facie hence meaning "your wife was unfaithful to you". Third, Saussure defined symbols as "icons" in the Peircean dichotomy of sign while Hjelmself included diagrams and games into the symbolic system (1943). According to Eco (1976), Saussure and Hjelmself spoke in fact of signs ruled by ratio difficilis where the expression maps. according to pre-established projection rules, some features of the corresponding content. In this sense, we can call a geographical map as symbol for once we alter, for example, the border between Indonesia and Malaysia, we can forecast what would happen in the real world. Fourth, many people associate symbols with metaphors, allegories, and other tropes. Wahab (1990) uses Cirlot's dictionary of symbols in order to help him reveal the meaning of 'universal metaphors'. Thus, a metaphor concerning darkness can be revealed by checking the meaning of the symbol 'darkness' in many cultures.

We usually can notice easily that in rhetorics and literature, the flouting of the four conversational maxims (Grice, 1975) can be used to create certain effects from the addressee. Metaphors, irony, hyperboles and such tropes violate the maxim of quality since they do not tell the truth (literally). When Khairil Anwar said " Aku ini binatang jalang", he literally lied for he could never be a wild animal. Yet, in facing such a blatant case of lying, the addressee normally faces no problem and can recognize that the poet probably intended to say something else. In fact, many metaphors can be disambiguated without vagueness. The metaphor concerning darkness is an example, we can know from the context that the meaning is "sadness" without looking onto the traditional symbolism which will even lead to a wrong path for in Cirlot (1971: 75-76), darkness symbolizes the primigenial chaos, not gloom. On the other hand, a reader may not rely on any pre-established rules when facing such a text as the following lines of Milton's

\section{L'Allegro :}

Hence loathed Melancholy

Of Cerberus and blackest Midnight born,

In Stygian cave forlorn

'Mongst horrid shapes, and shrieks, and sights

unholy,

Find out some uncouth cell,

Where brooding Darkness spreads his jealous wings,

The text can be approached in two ways. First, at the surface level we can start with the figure Melancholy. Any reader who has no stock of encyclopedia concerning Melancholy, Cerberus, Stygian cave might still be able to grasp a sense that 'this Melancholy was born of Cerberus and blackest Midnight in a cave called Stygia where there were horrid shapes, shrieks, and sights'. But such a too 
literal interpretation may be made more sensible by a reader with enough encyclopedia of Melancholy, Cerberus, and Stygian cave. Babb (in Carey and Fowler, 1968) points out that there are two opposed Renaissance attitudes toward melancholy. The first, originating in Galenic medicine, viewed it as a source of stupidity, fearfulness and illusions. The second, originating in Aristole's Problemata xxx stressed that all who have become eminent in philosophy, poetry, or the arts have been of melancholy temperament. The next encyclopedia that the writer must work upon is the Greek mythology of Cerberus and Styx (Stygian cave). In Greek mythology, Cerberus was told in the story of Hercules as a three-headed hell - hound whose throat bristled with serpents. He was the guardian of the abode of Pluto on the banks of the Stygian lake (Pluto's kingdom). Virgil once wrote that Aeneas heard shrieks which came from the souls of dead children as he passed the cave. At this stage, the reader will also be aware that the parentage of Melancholy as the child of Cerberus and the blackest midnight is merely Milton's invention. At the surface level, a reader may still be able to grasp the sense of the text.

However, the fact that we often find such a text alluding to mythology may convince us that there is something beyond the use. This brings us to the second kind of interpretation that will be labeled "symbolic mode" (Eco, 1986). Practically, symbolic mode is characterized by the interpreter's pragmatic decision to interpret the text symbolically. The pragmatic decision produces at the semantic level a new sign function, by associating new content- as far as possible, undetermined and vague- with expression already correlated to a coded content. This is especially applicable to a text such as mythology in English poetry for the text. when the mode is not realized interpretively, remains endowed with sense at its literal or figurative sense. Eco (1986) has shown that in the modern aesthetic experience, the possible contents are suggested by the co-text and by the intertextual traditions. The interpreter does not intend to discover an external truth but he makes the encyclopedia work its best. Unlike the mystical experience in which symbolic contents are suggested by a preceding tradition and the interpreter is convinced that they are not cultural units but referents, aspects of an extrasubjective and extracultural reality.

Thus we must firstly operate our encyclopedia (the co-text and the intertextual traditions) in a progressive manner during the symbolic interpretation of the mythology in English poetry. That is to say that the possible new contents are not pre- established (even according to rhetorical rules) but created during the progress of interpretation. In interpreting the myth of Cerberus in L'Allegro we can start with the co-text. Milton describes the dog as the parent of Melancholy together with the blackest midnight. If we relate this with the key words 'horrid shapes, shrieks, Darkness, uncouth cell, night raven', we are building an image of blackness, darkness which are the attributes given to Melancholy. But this is not sufficient to understand the meaning of the myth Cerberus in this poem. We must do an intertextual analysis. In the beginning of the twin poem Il Penseroso, Melancholy is described as black but in esteem such as Prince Memnon's sister, Himera:

Hail divinest Melancholy,

Whose saintly visage is too bright

To hit the sense of human sight

And therefore to our weaker view

O'erlaid with black staid wisdom's hue

Black, but such as in esteem,

Prince Memnon's sister might beseem,

Or that starred Ethiop queen that strove

To set her beauty's praise above

The sea nymphs, and their powers offended.

Thus here Melancholy is described as black but beautiful different from in L'Allegro where the blackness of Melancholy is horrible. Melancholy blackness refers to that of Himera (prince Memnon's sister) or the Ethiop queen (Cassiopeia) who was changed into a constellation (star) because she claimed to be more beautiful than the Nereids (sea nymphs). Then we have to look up at Babb who distinguishes two Rennaisance attitudes to melancholy which can be summarized as the damned melancholy (the source of stupidity, fearfulness and illusion) and divine melancholy (poets are of melancholy temperament). The meaning of the twin poems clearly support these opposed attitudes to melancholy. In L' Allegro, Milton rejects Melancholy (because of the terrible darkness) and preferred to follow Euphrosyne, the heart-easing Mirth as the symbol of youth and jollity. If we follow Dorian (in Carey and Fowler, 1968) who suggested that the poems are the autobiographical record of Milton that is whether he should suppress either 
the lighter or serious side of his nature, as man or as poet, we can conclude that in L'Allegro, Milton believes that living in lighter manner as man is better. Hence he concluded in the last line of this poem "Mirth with thee, I mean to live". Wherea in II Penseroso, Milton preferred a life as a poet. He considered the vain deluding joys (Mirth) as the brood of folly without father bred. Therefore, he concluded in the last lines that "these pleasures Melancholy give, and I with thee will choose to live". It is now obvious by contrasting the blackness of Melancholy in the two poems (representing the damned and the divine melancholy), the myth Cerberus symbolizes the evil genius that gives birth to poetic genius. This is in line with the Neoplatonic doctrine which saw the dog as the symbol of the evil genius (Cirlot, 1971: 42).

Since the symbolic mode interpretation uses the intertextual and intratextual analysis, the target is then to find the symbolic meaning of myths in mythology so that finally we can construct the semiotic system of mythology in English poetry. The procedures are started with the meaning of each myth in one individual work and then related to the meaning of the same myth in other works (even of different writers) before we finally determine the function of the myth. Let us compare the myth of Proserphine in the following three poems:

\section{Paradise Lost (Milton)}

Of Enna, where Proserphine gathering flowers

Herself a fairer flower by gloomy Dis

Was gathered, which cost Ceres all that pain

To seek her through the world; nor that sweet grove

Of Daphne by Orontes, and the inspired

Castallian spring, might with this Paradise

\section{Ode to Melancholy (Hood)}

Forgive, if somewhile I forget,

In woe to come the present bliss

As frighted Proserphine let fall

Her flowers at the sight of Dis

\section{Rhymes on the Road (Moore)}

Tis for the theft of Enna's flower from the earth

These urchins celebrate their dance of mirth
Round the green tree, like fays upon a heath

Those that are nearest linked in order brigh

Cheek after cheek, like rosebuds in a wreath:

And those more distant showing from beneath

The others' wings their little eyes of light

While see! Among the clouds, their eldest brother,

But just flown up, tells with a smile of bliss,

This prank of Pluto to his charmed mother

Who turns to greet the tidings with a kiss

By using a method of reading similar to the myth reading done by Levi-Strauss (in Culler, 1975:40) where he compares different myths, we could determine the underlying structure and hence the meaning. In the case of mythology in English poetry, we may see that it is easier to proceed rather than in Levi- Strauss' study since e there has been provided the cultural context which enables us to grasp the meaning which the poems convey so that we can check our explanation of details by the relevance to the meanings. Just like in Levi-Strauss' study, we may apply the so-called "spiral movement" in which one myth is used to elucidate another. The final result ought to be a coherent system in which each myth is studied and understood in its relation with the others. To explain an item or incident in a particular myth, we must not only consider its relation to other elements in a poem, but also try to determine how it is related to elements appearing in similar contexts in other poems. Thus we could finally gather that the myth of Proserphine in the three poems would be read as:

\begin{tabular}{|c|c|c|}
\hline Paradise Lost & Ode to Melancholy & Rhymes on the Road \\
\hline $\begin{array}{l}\text { Proserphine, like Eve was } \\
\text { captured by the king of } \\
\text { Hell, but she then became } \\
\text { queen of it, became sin. To } \\
\text { Miton, just as Eve } \\
\text { becomes the ally of Satan } \\
\text { when she tempt Adam to } \\
\text { eat with her, Proserphine } \\
\text { serves as the symbol of } \\
\text { "the material and spiritual } \\
\text { aspect of life" }\end{array}$ & $\begin{array}{l}\text { Proserphine, by letting her } \\
\text { flowers fall at the sight of } \\
\text { Dis (Pluto, king of the } \\
\text { underworld) seems to } \\
\text { symbolize the beginning of } \\
\text { human sins that is by the } \\
\text { loss of virginity given to } \\
\text { Satan }\end{array}$ & $\begin{array}{l}\text { The celebration of the loss of } \\
\text { the flower from Enna } \\
\text { (Prosepherine) by the urchins } \\
\text { indicate that this myth } \\
\text { symbolizes the loss of dignity } \\
\text { or virginity caused by Satan }\end{array}$ \\
\hline
\end{tabular}


From the three appearances of the myth Proserphine, we then can conclude that this myth symbolizes the "material and spiritual aspect of life" which, in traditional symbolism of Eve, is associated with woman who often causes man to commit a $\sin$

\section{MYTHOLOGY AND PEIRCEAN TRICHOTOMY OF SIGN}

In his study of literary history, Lotman (1970) proposes two kinds of aesthetics namely the identity aesthetics and the opposition aesthetics. The first is the characteristics of folklore, Dark Age works, and classisism including the ancient Asian cultures. They are all characterized by the strong faith in traditions by assuming the sameness or similarity between the sender's code and the receiver's. The opposition aesthetics takes place when the sender's code and the receiver's are different such as the ro manticism, realism, and Avant Garde works. Due to the distinction of aesthetics made by Lotman, we could characterize that the mythological texts belong to the identity aesthetic characterized by regularity like folktales studied by Propp (1958). Yet, as soon as the mythology is 'transformed' into one of the opposition aesthetics like English poetry, the nature changes radically. To interpret texts holding strong faith in tradition such as folklore, mythology, or any other identity aesthetics, we may use generative model with little difficulty due to the high degree of regularity of the texts. The opposition aesthetics, on the other hand, are not created without rules, but the rules are designed during the creative process and can be identified in the receptive process. We could not expect any regularity of meaning or function as the original text of mythology any more, instead, we are required to do a progressive interpretation by considering the intertextuality, intratextuality, and the co-text and the transformations, the juxtaposition. and intersections of various elements.

A careful reading of Peirce's semiotics may result in a conclusion that he never identified something as a mere symbol and as a mere icon. Concerning the characteristics of mythology in English poetry as an opposition aesthetics, we may then employ the trichotomy of signs as proposed by Peirce (1985) in order to reveal the model of reading and the relation of the sign, its object, and its interpretant First, the trichotomy of sign into rheme (the firstness such as the single myth of Bachus). Dicent (stacondness such as when myth 'Bacchus' is used in the poem
"Comus" as the father of the Comus and married to Circe), and Argument (thirdness/leading principle such as "the myth of Bacchus as the symbol of self annihilation). Thus, the reading process is started with our recognition of the single myth of Bacchus as a sign (firstness), followed by the secondness that is the myth Bacchus in the poetry as the father of Comus and the husband of Circe. Finally, by relating the sign (mythology in the anthropological sense) and the object (myth in poetry), we come to an argument (thirdness) that the myth Bacchus with his destructive power of wine and supported by the magical power of Circe symbolizes the 'self-annihilation'. Second, in trying to find the relationship between sign, object, and its interpretant, we use the trichotomy of sign as icon, index, and symbol. We use the concept of iconicity to indicate the similarity between the object and the sign. If we talk the causal relationship, for example between the myth of Bacchus and the myth in poetry that will lead us to question why Bacchus should be said to be parent of Comus together with Circe while in the original mythology it is not so, we then talk about indcx. Finally, we come to the highest degree of sign, symbol which has been discussed by using the symbolic mode.

\section{REFERENCES}

Carey, J and Fowler, A. 1968. The Poems of John Milton. London: Longman Group Ltd. Cirlot, J.E, 1971. A Dictionary of Symbols. Translated. by Sage, J. New York: Philosophical Library Inc

Cook, G. 1994. Discourse and Literature: The Interplay of Form and Mind. Oxford: Oxford University Press.

Culler, J. 1975. Structuralist Poetics. Ithaca: Cornell University Press.

Deely, J.N. 1982. Introducing Semiotic. Bloomington: Indiana University Press

Eco, U. 1976. A Theory of Semiotics. Bloomington: Indiana University Press.

Eco, U. 1986. On Symbols, in Deely, J, Williams, B and Kruse, F.E (eds). Frontiers in Semiotics (p. 153-180). Bloomington: Indiana University Press.

Fokkema, D.W and Kunne-Ibsch, E. 1994. Theories of Literature in the Twentieth Century. Translated. by Praptadiharja, J \& Silaban,K. 1998. Jakarta: Gramedia Pustaka Utama

Grice, H.P.1975. Logic and Conversation . in Cole, P \& Morgan, J.L (eds). Speech Acts, vol 3 of Syntax and Semantics. New York: Academic Press

Huck, C.S. 1976. Children's literature In the Elementary School. New York: Holt, Rinehart, and Winston 
Jacobson, R. 1960. Linguistics and Poetics. In Seheok, T.A.(ed). Style in Language. Cambridge: The M.I.T. Press

Lotman, J. 1970. The Structure of the Literary Text. Providence: Brown University Press Morris, C.W. 1938. Foundations of the Theory of Sign. Chicago: University of Chicago Press

Newton, K.M. 1990. Interpreting the Text. London : the Harvester Wheatsheaf

Peirce, C.S. 1985. Logic of Semiotic : the Theory of Signs. In Sebeok, T. (ed). Semiotics, An Introductory Anthology (p.4-23) Bloomington: Indiana University Press

Propp, V.1958. Morphology of the Folktale. Bloomington: Indiana Research Centre in Anthropology.

Sebeok, T.A. 1986. The Doctrine of Signs. In Deely, et. al (eds). Frontiers in Semiotics (p. 255-263). Bloomington: Indiana University Press

Wahab, A. 1990. Sepotong Model Tentang Metafora. In Aminuddin (ed). Pengembangan dan Penelitian Kualitatif Dalam Bidang Bahasa dan Sastra. Malang: Yayasan Asah dan Asuh

Widdowson, H.G. 1975. Stylistics and the Teaching of Literature. London: Longman 